\title{
ВПЛИВ ЛАЙМ-БОРЕЛІОЗУ ТА ЛЯМБЛІОЗУ НА ПЕРЕБІГ ТУБЕРКУЛЬОЗУ ЛЕГЕНЬ
}

\author{
Тернопільський національний медичний університет ім. І.Я. Горбачевського
}

\begin{abstract}
Мета дослідження - вивчити вплив супутніх Лайм-бореліозу (ЛБ), лямбліозу та їх поєднання на перебіг туберкульозу за виділенням мікобактерій $i$ поширенням патологічного прочесу в легенях.
\end{abstract}

Пацієнти і методи. Спостерігали 99 хворих на легеневий туберкульоз, які протягом 2015-2017 рр. перебували на стаціонарному лікуванні в Тернопільському обласному протитуберкульозному диспансері. Вплив супутнього ЛБ, лямбліозу та їх поєднання на перебіг туберкульозу вивчали за наявністю мікобактерій у харкотинні та клініко-рентгенологічними даними. М. tuberculosis виявляли на підставі мікроскопії мазка мокроти, посіву ії на живильні середовища і GeneXpert/RIF дослідження. Рентгенологічну картину в легенях оцінювали за допомогою рентгенографії і комп'ютерної томографрії органів грудної порожнини. ЛБ діагностували на підставі серологічного дослідження імунофрерментним методом на наявність антитіл до антигенів комплексу B. burgdorferi sensu lato з використанням тест-систем компанії Euroimmun AG (Німеччина). Лямблії виявляли методом триразової паразитоскопії калу після попередньої підготовки пачієнтів (прийом жовчогінного чаю). Статистичне опрацювання показників проводили з визначенням критерію Стьюдента (t) і непараметричного U-критерію Манна-Уїтні. Аналіз взаємозв'язку двох ознак проводили за даними коефріцієнту кореляції Пірсона (r) і коефріцієнту рангової кореляції Спірмена $(R)$.

Результати. Вогнищевий, інфрільтративний та дисемінований процеси туберкульозу значно частіше спостерігалися у пацієнтів з виділенням мікобактерій $(p<0,01-0,001)$. Частота виділення мікобактерій була найнижчою у пацієнтів без лямбліозу та ЛБ - у $54,8 \%$, найвищою - у хворих із супутнім лямбліозом - у 81,3 \% осіб $(p<0,01)$. Виявили прямий дуже сильний кореляційний зв'язок $(r=0,940, p<0,05)$ між дисемінованою фоормою ТБ і наявністю супутнього ЛБ у групі з ЛБ і у групі, де ЛБ поєднувався з лямбліозом. Сильний кореляційний зв'язок $(r=0,817, p<0,05)$ виявили між інфрільтративною формою ТБ і наявністю супутнього ЛБ у групі з ЛБ і у групі з поєднанням ЛБ і лямбліозу. Водночас між інфрільтративною фрормою ТБ і наявністю супутнього лямбліозу виявили помірний кореляційний зв'язок $(r=0,379, p<0,05)$. Відзначено тенденцію щодо частішого виділення мікобактерій у хворих з дисемінованою та інфрільтративною фрормами ТБ з супутніми ЛБ $i$ лямбліозом.

Висновки. Серед наявних фрорм ТБ легень у пацієнтів переважали інфрільтративна та дисемінована. Частота виділення мікобактерій була найвищою у хворих на ТБ легень у поєднанні з супутнім лямбліозом $(p<0,05)$. Дисемінована форма ТБ легень у пацієнтів була взаємопов'язана з наявністю супутнього ЛБ за сильним статистично значимим кореляційним зв'язком $(r=0,940, p<0,05)$.

Ключові слова: туберкульоз, Лайм-бореліоз, лямбліоз, виділення мікобактерій.

Туберкульоз (ТБ) продовжує залишатися важливою медичною та соціальною проблемою людства. Згідно 3 даними ВООЗ, ТБ є основною причиною смерті серед інфекційних хворих у світі, перевищуючи цей показник при ВІЛ-інфекції. У 2019 р. на ТБ захворіло 10 млн осіб та 1,2 млн померли [1]. В Україні у 2019 р. захворюваність становила 60,1 на 100000 населення, що на 3,5\% менше показника 2018 р., проте все ще перевищує епідемічні показники [2]. Ефективність лікування залежить не лише від раціонального використання етіотропних і патогенетичних засобів, але й від наявності супутніх захворювань, в тому числі інфекційної етіології [3-7].

Поширеність ТБ залишається високою в регіонах, які $є$ ендемічними для паразитарних і кров'яних інфеекцій, що може призвести до їх поєднання [7]. Враховуючи територіальні, кліматичні, соціально-економічні та етнічні особливості, у структурі найбільш поширених інсрекцій, окрім ВІЛ, виділяють також паразитарні, зокрема лямбліоз і ЛБ [8-12].

Західні області України, в тому числі й Тернопільська, $є$ ендемічними щодо ЛБ [10]. В Україні захворюваність на ЛБ у 2019 р. становила 10,6 на 100 тис. насе- 
лення. В Україні щорічно реєструють 30-40 тис. випадків лямбліозу, що приблизно відповідає ураженню 0,01 \% населення [11].

Враховуючи поліорганність ураження, схильність до хронізації патологічного процесу та несприятливу епідемічну ситуацію щодо ЛБ, лямбліозу та ТБ у світі та Україні зокрема, своєчасне їх виявлення, визначення особливостей клінічного перебігу цих інфекцій в поєднанні та призначення відповідного лікування є важливим і актуальним завданням практичної медицини.

Метою дослідження було вивчити вплив супутніх ЛБ, лямбліозу та їх поєднання на перебіг ТБ за виділенням мікобактерій і поширенням патологічного процесу в легенях.

\section{Пацієнти і методи}

Під спостереженням перебували 99 пацієнтів з ТБ, які протягом 2015-2017 рр. лікувались у стаціонарних умовах Тернопільського обласного протитуберкульозного диспансеру. Чоловіків було 77 (77,8 \%), жінок - 22 (22,2 \%), віком 18-76 років (у середньому - 46,6 $\pm 12,9)$. У 88 (88,9\%) хворих діагноз ТБ було встановлено вперше, в 11 (11,1 \%) - мав місце рецидив захворювання.

Діагноз туберкульозу встановлювали на підставі клініко-рентгенологічних, лабораторних та інструментальних даних відповідно до діючої МКХ 10. У 70 (70,7 \%) випадках діагноз підтверджено виявленням збудника - бактеріологічно (на підставі мікроскопії мазка мокроти, посіву її на тверде живильне середовище Левенштейна-Йєнсена, BACTEC, GeneXpert/RIF дослідження) у 65 (65,7 \%), гістологічним методом - у 5 (5,0 \%) хворих. У 29 (29,3 \%) хворих діагноз ТБ встановлено на підставі клініко-рентгенологічних даних. Рентгенологічну картину легень оцінювали за допо- могою рентгенографрії, томографрії та комп'ютерної томограсрії органів грудної порожнини.

ЛБ діагностували на підставі серологічного дослідження хворих імуносрерментним методом на наявність антитіл до антигенів комплексу B. burgdorferi sensu lato з використанням тест-систем компанії Euroimmun AG (Німеччина): антитіла класу М - тест-системою Anti-Borrelia burgdorferi ELISA (IgM), класу G - Anti-Borrelia plus VIsE ELISA (IgG). Відповідно до рекомендацій виробника, результат $\geq 22$ Од/мл вважали позитивним, від 16 до 22 Од/мл - проміжним, $\leq 16$ Од/мл - негативним.

Лямблії виявляли методом трикратної паразитоскопії калу після попередньої підготовки пацієнтів (прийом жовчогінного чаю).

Статистичне опрацювання показників проводили з визначенням критерію Стьюдента (t) і непараметричного U-критерію Манна-Уітні. Аналіз взаємозв'язку двох ознак проводили за даними коесріцієнта кореляції Пірсона (r) і коесріцієнта рангової кореляції Спірмена (R).

\section{Результати досліджень та їх обговорення}

Відповідно до поширеності процесу в легенях за рентгенологічною характеристикою пацієнти розподілилися таким чином: вогнищевий процес діагностовано у 3 (3,0 \%) хворих, інсрільтративний - у 45 (45,5\%), дисемінований - у 39 (39,4 \%) та з випотом у плевральній порожнині (плеврит) - у 12 (12,1 \%). Частіше виявляли інфрільтративну форму ТБ порівняно з дисемінованою, що збігається з даними інших авторів [4, 7].

Вогнищевий, інфільтративний та дисемінований процеси ТБ значно частіше спостерігалися у пацієнтів з виділенням мікобактерій ( $p<0,010,001)$ (табл. 1).

Клініко-рентгенологіна характеристика хворих на ТБ залежно від бактеріовиділення

\begin{tabular}{|c|c|c|c|c|c|c|}
\hline \multirow[t]{2}{*}{$\begin{array}{c}\text { Клінічна фрорма } \\
\text { ТБ }\end{array}$} & \multicolumn{2}{|c|}{$\begin{array}{c}\text { Число хворих } \\
\text { n=99 }\end{array}$} & \multicolumn{2}{|c|}{$\begin{array}{c}\text { МБТ (+) } \\
\text { (I група) } \\
\text { n=70 }\end{array}$} & \multicolumn{2}{|c|}{$\begin{array}{c}\text { МБТ (-) } \\
\text { (II група) } \\
\text { n=29 }\end{array}$} \\
\hline & абс. & $\%$ & абс. & $\%$ & абс. & $\%$ \\
\hline Вогнищева & 3 & $3,0 \pm 1,7$ & 2 & $66,7 \pm 5,6^{*}$ & 1 & $33,3 \pm 8,7$ \\
\hline Інорільтративна & 45 & $45,5 \pm 5,0$ & 35 & $77,8 \pm 5,0 *$ & 10 & $22,2 \pm 7,7$ \\
\hline Дисемінована & 39 & $39,4 \pm 4,9$ & 28 & $71,8 \pm 5,4^{*}$ & 11 & $28,2 \pm 8,3$ \\
\hline 3 плевритом & 12 & $12,1 \pm 3,3$ & 5 & $41,7 \pm 5,9$ & 7 & $58,3 \pm 9,1$ \\
\hline
\end{tabular}

Примітка: * - достовірність ( $<<0,01-0,001)$ різниці показників між I і II групами хворих.

ЛБ як супутню патологію діагностовано у 25 (25,2 \%) хворих на ТБ, що перевищує його частоту серед насе- лення Італії, Словакії та наближається до показників у профресійних групах ризику (працівники лісу) [5, 7]. 


\section{ОРИГІНАЛЬНІ ДОСЛІДЖЕННЯ}

Лямбліоз як супутню патологію ТБ діагностовано у 64 (64,6 \%) хворих, що перевищує дані, отримані іншими авторами [3, 5].

Відповідно до наявності супутніх інсеекційних захворювань і з метою з'ясування їх впливу на ТБ пацієнтів було розділено на такі групи: І - ТБ без лБ і лямб- ліозу- 31 пацієнт, II - ТБ у поєднанні з ЛБ - 25 хворих, III - ТБ у поєднанні з лямбліозом - 64 особи, IV - ТБ разом з ЛБ і лямбліозом - 21 хворий.

Частота виділення мікобактерій туберкульозу була найнижчою у пацієнтів I групи - у 54,8 \%, найвищою у пацієнтів III групи - у 81,3 \% осіб (р<0,01) (табл. 2).

Таблиця 2

Частота виділення мікобактерій у хворих на легеневий ТБ за наявності супутніх ЛБ і лямбліозу

\begin{tabular}{|c|c|c|c|c|c|c|c|c|}
\hline \multirow[t]{2}{*}{ Бактеріовиділення } & \multicolumn{2}{|c|}{$\begin{array}{c}\text { ТБ } \\
\text { (I група) } \\
\text { n=31 }\end{array}$} & \multicolumn{2}{|c|}{$\begin{array}{c}\text { ТБ+лБ } \\
\text { (II група) } \\
\text { n=25 }\end{array}$} & \multicolumn{2}{|c|}{$\begin{array}{c}\text { ТБ+лямбліоз } \\
\text { (III група) } \\
\text { n=64 }\end{array}$} & \multicolumn{2}{|c|}{$\begin{array}{c}\text { ТБ+лБ+лямбліоз } \\
\text { (IV група) } \\
\text { n=21 }\end{array}$} \\
\hline & абс. & $\%$ & абс. & $\%$ & абс. & $\%$ & абс. & $\%$ \\
\hline MБТ (+) & 17 & $54,8 \pm 8,9$ & 17 & $68,0 \pm 9,3$ & 52 & $81,3 \pm 4,9^{*}$ & 16 & $76,2 \pm 9,3$ \\
\hline MБТ (-) & 14 & $45,2 \pm 8,9$ & 8 & $32,0 \pm 9,3$ & 12 & $18,7 \pm 4,9$ & 5 & $23,8 \pm 9,3$ \\
\hline
\end{tabular}

Примітка: * - достовірність ( $<<0,01)$ різниці показників між I і III групами хворих.

Виявили прямий дуже сильний кореляційний зв'язок $(r=0,940, p<0,05)$ між дисемінованою формою ТБ та наявністю супутнього ЛБ у групах II та IV. Сильний кореляційний зв'язок $(r=0,817, p<0,05)$ виявили між індрільтративною формою ТБ і супутнім ЛБ у групах II і IV. Водночас між інфрільтративною фрормою ТБ та наявністю супутнього лямбліозу у III і IV групах виявили помірний кореляційний зв'язок ( $r=0,379, p<0,05)$. Встановлено наявність обернених кореляційних зв'язків між інфрільтративною $(r=-0,402, r=-0,866, r=-0,328, p<0,05)$ та дисемінованою ( $r=-0,940, r=-0,417, r=-0,392, p<0,05)$ фрормами ТБ і наявністю супутніх ЛБ та лямбліозу чи їх поєднання між I i II, III, IV групами відповідно. Таким чином, інорільтративну й дисеміновану форму ТБ частіше виявляли за наявності супутніх лБ і лямбліозу.

Відзначено тенденцію щодо частішого виділення мікобактерій у хворих IV групи з дисемінованою фрормою ТБ, порівняно з пацієнтами I групи - у $(81,8 \pm 11,6)$ проти $(54,5 \pm 15,0) \%$ випадків відповідно. Таку ж тенденцію виявлено у хворих III групи з інфільтративною фрормою ТБ, порівняно з пацієнтами II групи - у $(85,2 \pm 6,8)$ проти $(63,6 \pm 14,5)$ \% випадків відповідно.

За даними літератури, в Ефріопії серед одноразово копроскопічно обстеженого 91 хворого на ТБ з виділенням мікобактерій кишкові паразитози виявлено у 20 (22\%) осіб, найчастіше G. lamblia - у 8 (33,3 \%) випадків, дещо рідше $A$. lumbricoides та $H$. nana - по 4 (16,7 \%) пацієнтів [10]. В Індії [11] серед 118 пацієнтів з ТБ легень бактеріовиділення діагностовано у 84 (71,18 \%) осіб. Після триразового копроскопічного обстеження гельмінти виявили у 28 (87,5 \%) пацієнтів, протозойні інвазії - у 4 (12,5 \%). Найпоширенішою інвазією був анкілостомоз (у 66,6 \% випадку). Варто зазначити, що поширеність паразитозів була вищою у пацієнтів з бактеріовиділенням, ніж без нього - у 26 (31,0 \%) проти 6 (17,0 \%) випадків відповідно, що узгоджується з отриманими нами результатами. Встановлено, що в ендемічних регіонах Росії показники інфікування трематодами коливаються від 47,3 до 60,3 \%. Серед 189 хворих на ТБ із супутніми трематодозами (клонорхоз, нанофрієтоз, метагонімоз) у структурі клінічних фрорм також переважав інсрільтративний процес у легенях (73,5 \% осіб), а мікобактерії виявляли у 69,8 \% пацієнтів, у групі без трематодозів - у 80,5 і 65,2 \% відповідно [12].

Нами ЛБ не виявлено у жодного хворого з вогнищевою фрормою ТБ, водночас лямбліоз встановлено у 2 пацієнтів. ЛБ діагностовано у 2 хворих 3 плевритом, причому в обох хворих він поєднувався з лямбліозом. Варто відзначити, що виділення мікобактерій спостерігали лише в 1 пацієнта з лБ.

\section{Висновки}

1. Серед наявних фрорм ТБ легень переважали інфрільтративна та дисемінована.

2. Частота виділення мікобактерій була найвищою у хворих на ТБ легень у поєднанні з супутнім лямбліозом.

3. Інфрільтративну й дисеміновану форми ТБ частіше виявляли за наявності супутніх ЛБ і лямбліозу. 


\section{ОРИГІНАЛЬНІ ДОСЛІДЖЕННЯ}

\section{Література}

1. World Health Organization, Global Tuberculosis Report 2020: WHO Report 2020, Geneva. -2020. - 232 p.

2. Туберкульоз. Центр громадського здоров'я МОЗ України. [Електронний ресурс] Режим доступу: https://phc.org.ua/kontrolzakhvoryuvan/tuberkuloz

3. Влияние сопутствующих кишечных паразитозов на некоторые показатели иммунного статуса у больных туберкулёзом лёгких / Н.А. Давис, Ж.И. Исламова, Н.Н. Парпиева [и др.] // Туберкулез и болезни легких. - 2012. - Т. 89, № 2. - С. 47-50.

4. Фещенко Ю.І. Сучасні тенденції вивчення проблем туберкульозу / Ю.І. Фещенко // Укр. пульмонол. журнал. - 2019. № 1. - C. 8-24.

5. Intestinal parasites co-infection and associated factors among active pulmonary tuberculosis patients in selected health centers, Addis Ababa, Ethiopia: unmatched case control study / A. Alemu, A. Kebede, B. Dagne, [et al.] // BMC infectious diseases. 2019. - Vol. 19(1). - P.407. https://doi.org/10.1186/s12879-019-4009-0

6. Prevalence of intestinal parasitic infections among pulmonary tuberculosis patients in a Tertiary Care Hospital, Bhubaneswar, Odisha, India / Kumudini Panigrahi, Amrita Jena, Pratima Singh [et al.] // Journal of Clinical and Diagnostic Research. - 2019. - Vol.13(8). - P. DC12DC15. https://www.doi.org/10.7860/JCDR/2019/41590/13067
7. Кораблев В.Н. Клиника и лечение больных туберкулезом сопутствующими эндемичными хроническими трематодозами: автореф. дис. д-ра мед. наук: 14.01.26 / В.Н. Кораблев // Центральный научно-исследовательский институт туберкулеза Российской Академии Медицинских Наук. - М., 1992. - 33 с.

8. Інфекційні хвороби у загальній практиці та сімейній медицині / За ред. М.А. Андрейчина.- Тернопіль: ТДМУ, Укрмедкнига, 2007.- 500 c.

9. Epidemiological situation of Lyme borreliosis in the PolishBelarusian borderland in the years 2012-2016 (Podlasie Province and Grodno Region) / A.L. Sovkich, A. Pańczuk, M. Kozioł-Montewka [et al.] // Health Problems of Civilization. - 2017. - Vol. 11, N. 2. - P.71-79.

10. Частота серопозитивних осіб до борелій серед працівників лісових господарств Житомирської, Хмельницької та Волинської областей / М.І. Шкільна, М.А. Андрейчин, М.М. Корда [та ін.] // Інфекційні хвороби.- 2018.- № 3 (93).- С. 18-25.

11. Малий В.П. Лямбліоз / В.П. Малий // Клінічна імунологія. Алергологія. Інфектологія. - 2014. - № 3 (72). - С. 35-43.

12. Seroepidemiological study of Lyme borreliosis among forestry workers in southern Poland / A. Buczek, A. Rudek, K. Bartosik [et al.] // Ann. Agric. Environ. Med. - 2009. - Vol. 16. - P. 257-261.

\section{References}

1. World Health Organization, Global Tuberculosis Report 2020: WHO Report 2020. (2020). Geneva, 232 p.

2. Tuberculosis. Public health center $\mathrm{MOH}$ of Ukraine. [E-resourse]. https://phc.org.ua/kontrolzakhvoryuvan/tuberkuloz [in Ukrainian].

3. Davis, N.A., Islamova, Zh.I., Parpieva, N.N., Belocercovec, V.G., Osipova, S.O. (2012) Vlijanie soputstvujushhih kishechnyh parazitozov na nekotorye pokazateli immunnogo statusa u bol'nyh tuberkuljozom ljogkih [The effect of concomitant intestinal parasitoses on some indicators of the immune status in patients with pulmonary tuberculosis]. Tuberkulez i bolezni legkih, 89(2), 47-50 [in Russian].

4. Feshchenko, Yu.I. (2019). Current trends in the study of tuberculosis. Ukr. pulmonol. zhurnal - Ukrainian Pulmonology Journal, 1, 8-24 [in Ukrainian].

5. Alemu, A., Kebede, A., Dagne, B., Amare, M., Diriba, G., Yenew, B., \& Desta, K. (2019) Intestinal parasites co-infection and associated factors among active pulmonary tuberculosis patients in selected health centers, Addis Ababa, Ethiopia: unmatched case control. BMC infectious diseases, 19(1), 407. https://doi.org/10.1186/ s12879-019-4009-0

6. Kumudini Panigrahi, Amrita Jena, Pratima Singh, Ipsa Mohapatra, Priya Ranjan Lenka, Jagadananda Jena (2019). Prevalence of intestinal parasitic infections among pulmonary tuberculosis patients in a Tertiary Care Hospital, Bhubaneswar, Odisha, India. Journal of Clinical and Diagnostic Research, 13(8), DC12-DC15. https://www. doi.org/10.7860/JCDR/2019/41590/13067 


\section{THE INFLUENCE OF LYME BORRELIOSIS AND GIARDIASIS ON THE COURSE OF PULMONARY TUBERCULOSIS}

\author{
L.P. Melnyk \\ I. Horbachevsky Ternopil National Medical University
}

SUMMARY. The aim of the study was to identify the influence of concomitant Lyme borreliosis (LB), giardiasis and their combination on the course of tuberculosis by mycobacteria excretion and the spread of the pathological process in lungs.

Patients and Methods. We observed 99 patients with tuberculosis treated at the Ternopil Regional TB Dispensary during 2015-2017. The influence of concomitant $L B$, giardiasis and their combination on the course of tuberculosis was studied by the presence of mycobacteria excretion, clinical and radiological data. M. tuberculosis was detected on the basis of sputum smear microscopy, culture on nutrient media and GeneXpert / RIF studies. The radiographic picture in the lungs was evaluated by radiography and computed tomography of the thoracic cavity. $L B$ was diagnosed on the basis of serological testing by enzyme-linked immunosorbent assay for the presence of antibodies to antigens of $B$. burgdorferi sensu lato using test systems from Euroimmun AG (Germany). Giardia was detected by triple parasitoscopy of feces after preliminary preparation of patients (taking choleretic tea). Statistical processing of indicators was performed with the definition of Student's criterion ( $t$ ) and. nonparametric Mann-Whitney $U$-test. The analysis of the relationship between the two traits was performed according to the Pearson correlation coefficient ( $r$ ) and Spearman's rank correlation coefficient $(R)$.

Results. Focal, infiltrative and disseminated processes of tuberculosis were significantly more common in patients with mycobacteria excretion ( $p<0.01-0.001)$. The frequency of mycobacterial excretion was the lowest in patients without giardiasis and LB - in $54.8 \%$, the highest - in patients with concomitant giardiasis in $81.3 \%$ of people $(p<0.01)$. A direct very strong correlation $(r=0.940, p<0.05)$ was found between the disseminated form of TB and the presence of concomitant $L B$ in the $L B$ group and in the group where $L B$ was associated with giardiasis. A strong correlation ( $r=0.817$, $p<0.05)$ was found between the infiltrative form of TB and the presence of concomitant $L B$ in the group with $L B$ and in the group with a combination of $L B$ and giardiasis. It should be noted that a moderate correlation was found between the infiltrative form of TB and the presence of concomitant giardiasis $(r=0.379, p<0.05)$. There is a tendency for more frequent isolation of mycobacteria in patients with disseminated and infiltrative forms of TB with concomitant $L B$ and giardiasis.

Conclusions. Among the available forms of pulmonary TB in patients, infiltrative and disseminated prevailed. The incidence of mycobacteria excretion was highest in patients with pulmonary TB in combination with concomitant giardiasis $(p<0.05)$. The disseminated form of pulmonary TB in patients was correlated with the presence of concomitant $L B$ by a strong statistically significant correlation $(r=0.940, p<0.05)$.

Key words: tuberculosis; Lyme borreliosis; giardiasis; mycobacteria excretion.

\section{Відомості про автора:}

Мельник Лариса Павлівна - асистент кафедри інфекційних хвороб з епідеміологією, шкірними та венеричними хворобами Тернопільського національного медичного університету ім. І.Я. Горбачевського; e-mail: melnyk_Ip@tdmu. edu.ua

Information about the author:

Melnyk L.P. - MD, assistant professor of the Department of Infectious Diseases with Epidemiology, Dermatology and Venerology I. Horbachevsky Ternopil National Medical University; e-mail: melnyk_Ip@tdmu.edu.ua

Конорлікт інтересів: немає.

The author has no conflict of interest to declare.

Отримано 18.12.2020 р. 